\title{
“Super-Robust" Peacekeeping Mandates in Non-International Armed Conflicts under International Law
}

\section{Marco LONGOBARDO*}

\begin{abstract}
Since 2013, the United Nations Security Council has tasked some peacekeeping forces with combat operations against armed groups in the context of non-international armed conflicts. In the framework of their mandates, peacekeepers' main responsibilities are to protect civilians and support the local central government in regaining full control over its territory, while launching offensive military operations against armed groups that go well beyond self-defence or the defence of civilians. Due to their offensive features, these mandates are called here "super-robust mandates" in order to emphasize the increased armed force that they can employ in comparison to traditional robust mandates. These super-robust mandates raise several concerns regarding their compatibility with the principles at the basis of peacekeeping operations and their effectiveness. After briefly outlining the evolution of peacekeeping, this article explores the compatibility of super-robust mandates with the principles of peacekeeping, their characterization as forcible interventions of the Security Council in non-international armed conflicts, and their suitability to reach a just and stable post-conflict arrangement. This article relies on case studies involving the practice of missions currently deployed in the Democratic Republic of Congo, in Mali, in Central African Republic, and in South Sudan.
\end{abstract}

Keywords: peacekeeping - protection of civilians - authorization to the use of armed force - MINUSCA MINUSMA - MONUSCO -UNMISS

[C] onsent, neutrality/impartiality and the use of force in self-defence oscillate between legal fiction and legal reality. Even as a fiction, they are important ontological myths. ${ }^{1}$

\section{(A) INTRODUCTION}

This article explores certain controversial international law issues ${ }^{2}$ pertaining to some recent United Nations (UN) peacekeeping mandates that are characterized by the authorization of the use of unprecedented offensive armed force. This article focuses on the United Nations

\section{¿ Article received on 15 June 2020, accepted on 14 September 2020 and published on 31 December 2020}

* Lecturer in International Law, University of Westminster. Internet references were last accessed on 01 June 2020 when the article was completed. Thanks to my students of academic years 2017/2018, 2018/2019, and 2019/2020 at the University of Westminster for having discussed with me these issues. Since this article has been finalized during a period of lockdown due to the Covid19 pandemic, great thanks to all the colleagues that have helped with locating resources that were no longer available. Email: m.longobardo1@westminster.ac.uk.

1 N. Tsagourias, 'Consent, Neutrality/Impartiality and the Use of Force in Peacekeeping: Their Constitutional Dimension', 11 JCSL (2006) 465-482, at 482 [doi:10.1093/jcsl/krl016].

2 For different perspectives, see C.T. Hunt, 'All Necessary Means to What Ends? The Unintended Consequences of the "Robust Turn" in UN Peace Operations", 24 International Peacekeeping (2017) 108-131 [doi:10.1080/13533312.2016.1214074]; L.M. Howard and A.K. Dayal, 'The Use of Force in UN Peacekeeping', 72 International Organizations (2018) 71-103 [doi:10.1017/S0020818317000431]. 
Organization Stabilization Mission in the Democratic Republic of Congo (MONUSCO), the most robust peace mission so far, the United Nations Multidimensional Integrated Stabilization Mission in Mali (MINUSMA), the United Nations Multidimensional Integrated Stabilization Mission in the Central African Republic (MINUSCA), and the United Nations Mission in South Sudan (UNMISS). Due to the degree of force employed by these missions, this article assesses whether they still fall into the legal category of peacekeeping and whether they are effective to protect civilians.

At a terminological level, these mandates are called here "super-robust" to emphasize that the use of armed force authorized therein is unprecedented, extremely proactive, and clearly offensive in nature. The expression "stabilization mandates", that is sometimes employed in relation to MONUSCO, MINUSMA, and MINUSCA, ${ }^{3}$ is not used here since it is not helpful to better understand the legal problems explored by this article. Due to space constraints, this article does not specifically address peacekeeping missions established by regional organizations, whether authorized by the UN Security Council (UNSC) or not. ${ }^{4}$

In order to understand the novelty posed by super-robust mandates, the article needs to describe the evolution of peacekeeping from its traditional understanding to robust mandates and beyond. Accordingly, firstly, this article briefly describes the genesis of peacekeeping and its evolution, analysing the original model under the three basic principles of peacekeeping (non-use of armed force, consent, and neutrality/impartiality) and the changes to that model leading towards robust mandates around the 1990s (Section 2). Section 3 explores the concept of robust mandates and how the UNSC and other UN bodies have interpreted extensively the three basic principles of peacekeeping in order to adapt them to new needs. In Section 4 , the rules on the use of armed force under super-robust mandates (MONUSCO, MINUSMA, MINUSCA, and UNMISS) are analysed in order to ascertain their difference with robust mandates and their compatibility with the principles of peacekeeping, even in their broader later interpretation. Section 5 compares super-robust mandates to operations under Article 42 of the UN Charter and to UNSC's authorizations of the use of armed force, concluding that these missions do not fall into these categories, but rather, should be seen as forcible UNSC's interventions in noninternational armed conflicts (NIACs). The success of MONUSCO, MINUSMA, MINUSCA, and UNMISS in relation to the protection of civilians and the attainment of a fair transition from a NIAC to peace is questioned in Section 6. Finally, Section 7 summarizes the conclusions reached

3 See A. Gilder, "The Effect of "Stabilization" in the Mandates and Practice of UN Peace Operations', 66 NILR (2019) 47-63 [doi:10.1007/s40802-019-00128-4].

4 On this topic, see, e.g., U. Villani, 'Les rapports entre l'ONU et les organisations régionales dans le domaine du mantien de la paix', 290 RCADI (2001) 225-436 [doi:10.1163/1875-8096_pplrdc_A9789041116116_02]; M.A. Plana, La regionalización de las Operaciones de la Paz. África y Oriente Medio, 5 REEI (2002) 1-26; A.M. de Luna Barrios, Las operaciones de mantenimiento de la paz de las organizaciones internacionales de carácter regional (Dykinson, Madrid, 2013); G. Cellamare, Le operazioni di peacekeeping delle organizzazioni regionali (Cacucci, Bari, 2015 ); E. Cimiotta, L'uso della forza nei rapporti tra Nazioni Unite e organizzazioni regionali e sub-regionali (Jovene, Napoli, 2018). 
by this article, emphasizing that super-robust mandates are not in line with the principles of peacekeeping and are not an effective tool to protect civilians and reach a just and durable peace.

\section{(B) THE EARLY EVOLUTION OF PEACEKEEPING OPERATIONS}

\section{(1) Preliminary Remarks}

UN peacekeeping missions are often dispatched by the UNSC to protect civilians and lead the transition from a situation of NIAC to peace. Over time, peacekeeping missions have evolved significantly, raising a number of legal issues along the way. ${ }^{5}$ The UN Charter does not explicitly refer to peacekeeping missions, but rather, they are an invention of the UN General Assembly (UNGA), which was quickly endorsed by the UNSC. States have accepted as lawful the deployment of peacekeeping missions, which are seen as grounded in the powers conferred to the UNSC and to the UNGA in the field of the maintenance of international peace and security. ${ }^{6}$ As a result of the lack of an explicit legal basis in the UN Charter, peacekeeping missions, although subject to the international law rules and principles binding upon the UNSC and the UN generally, ${ }^{7}$ are mainly governed, case-by-case, by their mandates and by the agreements concluded between the UN and the States on whose territory the missions are deployed. As a result, peacekeeping missions are an extremely flexible tool that can be employed to address a variety of different scenarios. For instance, the UN has dispatched peacekeepers to monitor elections, to maintain buffer zones between belligerents, to support peace processes after armed conflicts, to disarm armed groups pursuant to peace agreements, etc. Although this article focuses mainly on the military components of some super-robust missions, MONUSCO, MINUSMA, MINUSCA, and UNMISS also undertake a number of responsibilities unrelated to the use of military force.

The governance of transitions and post-conflict situations through UN institutional processes is clearly one of the goals of the organized international community. UN peacekeeping missions

5 See D.W. Bowett, United Nations Forces: A Legal Study of United Nations Practice (Stevens, London, 1964); J. Ballaloud, L'ONU et les opérations de maintien de la paix (Pedone, Paris, 1971); P.A. Fernández Sanchez, Operaciones de las Naciones Unidas para el mantenimiento de la paz (Universidad de Huelva, Huelva, 1998); L. Pineschi, Le operazioni delle Nazioni Unite per il mantenimento della pace (Cedam, Padova, 1998); G. Cellamare, Le operazioni di peace-keeping multifunzionali (Giappichelli, Torino, 1999); P. Gargiulo, Le Peace Keeping Operations delle Nazioni Unite (Editoriale Scientifica, Napoli, 2000); A.J. Bellamy and P.D. Williams, Understanding Peacekeeping (2 $2^{\text {nd }}$ ed., CUP, Cambridge, 2010); M. Frulli, Le operazioni di peacekeeping delle Nazioni Unite: continuità di un modello normative (Editoriale Scientifica, Napoli, 2012); T. Gill et al. (eds), Leuven Manual on the International Law Applicable to Peace Operations (CUP, Cambridge, 2017); P.A. Fernández-Sánchez (ed.), Peacekeeping: Global Perspectives, Challenges and Impacts (Hauppauge, New York, 2018).

6 For an overview on the different theories on the legal basis of peacekeeping operations, see A. Orakhelashvili, 'The Legal Basis of the United Nations Peace-Keeping Operations', 43 Virginia Journal of International Law (2003) 485-524; A.J. Iglesias Velasco, 'El marco jurídico de las operaciones de mantenimiento de la paz de Naciones Unidas', Foro, Nueva época (2005) 127-177 [doi:10.5209/FORO]; R. Higgins et al. (eds), Oppenheim's International Law: United Nations (OUP, Oxford, 2017), at 1039-1055.

7 Appeals Chamber, Prosecutor v. Dusko Tadić, Case no. IT-94-1, Judgment of 2 October 1995, para. 28. 
allow the UN to exercise very flexible forms of assistance and even governance in relation to transition, State-building, and post-conflict governance. ${ }^{8}$ As a result of peacekeeping flexibility and of their involvement in NIACs with State-building responsibilities, peacekeeping missions today are very different and barely resemble the first mandates created more than seven decades ago. Simply put, peacekeeping has evolved, free from the constraints of written legal basis, to respond to the needs of different scenarios and different historical moments.

This reality of the flexibility of peacekeeping, and the actual variety of mandates that have been adopted, adjusted, de jure or de facto modelled on specific situations, make it difficult to identify the boundaries of peacekeeping. As a result, authors have suggested that different kinds of operations should be labelled and treated in a different way, acknowledging that most proactive and militarized mandates cannot be reconciled with the idea of peacekeeping. ${ }^{9}$ However, there is still today a minimum common denominator that can be identified in the ongoing relevance of the consent of the host State(s). ${ }^{10}$ Whether this is enough to define a coherent legal model, ${ }^{11}$ or whether that minimum common denominator has been so watered down that today almost everything under a UN flag can be classified as peacekeeping ${ }^{12}$ is a matter of debate.

The lack of written basis in the UN Charter, the huge degree of flexibility of mandates, and the deployment of peacekeeping operations in different scenarios are reflected by a number of official documents adopted by the UN Secretary-General or under his mandate to monitor and guide the evolution of peacekeeping. ${ }^{13}$ These internal administrative acts of the UN mix legal and policy elements, partially acknowledging the UNSC's practice on peacekeeping, partially trying to direct the UNSC in its future actions. Although these documents do not create legal obligations,

8 Generally, on the role of the UN in post-conflict situations, see Y. Daudet, 'L'action des Nations Unies en matière d'administration territoriale', 6 Cursos Euromediterráneos Bancaja de Derecho Internacional (2002) 459; S. Chesterman, You, The People. The United Nations, Transitional Administrations, and State-Building (OUP, Oxford, 2004); P. Picone, 'Le autorizzazioni all'uso della forza tra sistema delle Nazioni Unite e diritto internazionale generale', 88 RDI (2005) 5, at 45-56; M. J. Aznar, Administración internacionalizada del territorio (Atelier, Barcelona, 2008); I. Ingravallo, Il Consiglio di sicurezza e l'amministrazione diretta dei territori (Editoriale Scientifica, Napoli, 2008); C. Stahn, The Law and Practice of International Territorial Administration (CUP, Cambridge, 2008); R. Wilde, International Territorial Administration (OUP, Oxford, 2008).

9 T. Gill, 'Peace Operations', in T. Gill and D. Fleck (eds), The Handbook of the International Law of Military Operations (2 ${ }^{\text {nd }}$ ed., OUP, Oxford, 2015) 153.

10 The element of consent is assayed in particular infra, Section 3.3.

11 As argued by Frulli, supra n. 5.

12 P. Picone, 'Il peace-keeping nel mondo attuale: tra militarizzazione e amministrazione fiduciaria', $79 \mathrm{RDI}$ (1996) 5-34.

13 See, among others, An Agenda for Peace: Preventive Diplomacy, Peacemaking and Peace-Keeping, A/47/277S/24111, 17 June 1992; Supplement to an Agenda for Peace, A/50/60-S/1995/1, 25 January 1995; Report of the Panel on United Nations Peace Operations, A/55/305-S/2000/809, 21 August 2000 (hereinafter: 'Brahimi Report'); A More Secure World: Our Shared Responsibility. Report of the High-level Panel on Threats, Challenges and Change, A/59/565, 2 December 2004; UN Department of Peacekeeping Operations, United Nations Peacekeeping Operations Principles and Guidelines (UN, New York, 2008) (hereinafter: 'Capstone Doctrine'); UN Department of Peacekeeping Operations, New Partnership Agenda: Charting a New Horizon for UN Peacekeeping (UN, New York, 2009); Report of the High-Level Independent Panel on Peace Operations on Uniting our Strengths for Peace: Politics, Partnership and People, A/70/95-S/2015/446, 17 June 2015 (hereinafter: 'HIPPO Report'). 
they are crucial to understanding the evolution of peacekeeping.

\section{(2) Genesis and Crisis of the Traditional Model}

Usually, scholars consider the United Nations Emergency Force (UNEF I), which was deployed in 1956 by the UNGA in the aftermath of the Suez Crisis, ${ }^{14}$ to be the first true peacekeeping operation. ${ }^{15}$ According to the UNGA's mandate, UNEF I's peacekeepers could use armed force only in personal self-defence, ${ }^{16}$ the mission should have been conducted neutrally with regard to the parties of the armed conflict in the context of which the mission was dispatched, ${ }^{17}$ and the consent of the belligerents was at the basis of the deployment of the UN troops. ${ }^{18}$ Lacking enforcement powers, these operations could have been effective only with the co-operation of the parties that had agreed to their deployment. ${ }^{19}$ The UNSC soon realized that the UNGA had found a good stratagem for the monitoring and settlement of international disputes concerning potentially explosive situations for international peace and security. ${ }^{20}$ As a result, the UNSC was quick at appropriating the UNGA's idea, basing the future mandates on the UNEF I model.

Since then, the limitation on use of armed force to situations of self-defence, the consent of the territorial States, and the neutrality of the mission have been considered the so-called basic principles or pillars of peacekeeping, which have guided the creation of future UN peacekeeping missions. ${ }^{21}$ These principles were particularly suitable for peacekeeping operations tasked with the monitoring of ceasefires, the support for peace processes at the end of international armed conflicts, and the implementation of peace treaties. The missions were seen as "exclusively international in character in that they relate to armed conflict among State" ${ }^{22}$ This model proved sufficiently versatile to address issues arising from "multidimensional" peacekeeping, that is, when the UN missions were requested to perform a number of military, police, and civil tasks in order to improve the security of civilians involved in armed conflicts and the building of a safe institutional environment. ${ }^{23}$

14 GA Res. 1001 (ES-I), 7 November 1956.

15 Earlier UN missions with purely observer functions usually are not considered to be peacekeeping missions (C. Henderson, The Use of Force and International Law (CUP, Cambridge, 2018), at 176).

16 See Summary Study of the Experience Derived from the Establishment and Operation of the Force, A/3943, 9 October 1958, para. 179.

17 Ibid., at para. 149.

$18 \quad$ Ibid. para. 132.

19 F.-T. Liu, 'United Nations Peacekeeping Operations: their Importance and their Limitations in a Polarized World', 201(1) RCADI (1987) 385, at 391-392 [dx.doi.org/10.1163/1875-8096_pplrdc_A9789024737000_03].

20 The UNGA had already claimed a complementary role in the maintenance of international peace and security through the Uniting for Peace, GA Res. 377(V) A, 3 November 1950.

21 See Henderson, supra n. 15, at 173-176.

22 Summary Study, supra n. 16, at para. 13.

23 See UN Department of Peacekeeping Operations, Handbook on United Nations Multidimensional Peacekeeping Operations (UN, New York, 2003). 
However, the traditional peacekeeping principles shaped on inter-State conflicts proved inadequate to guarantee the fulfilment of the mandate and, in particular, the protection of civilians from attacks conducted by armed groups when missions were deployed in territories torn by NIACs. These groups usually do not cooperate with the UNSC, which is a forum mainly for inter-State relations, and their voices have significantly less weight for the UNSC than those of the governments against which the armed groups are fighting.

This factual situation put the principles of peacekeeping under an enormous strain since the need to protect civilians from armed groups resulted in the necessity to employ armed force beyond individual self-defence. As the UN troops were mainly deployed thanks to the consent of the government against which these groups were fighting, the peacekeepers were often perceived as obstacles to the attainment of the armed groups' goals, and, thus, their safety and freedom of movement were severely impaired.

For instance, the UN mission deployed in the Congo in the 1960's to assist the consolidation of the Congolese government's authority (the United Nations Operation in the Congo, ONUC) ${ }^{24}$ tested the limits of the traditional model. Although the UNSC had increased the degree of force authorized beyond the traditional model due to the volatile situation on the ground, ${ }^{25}$ the mission had to adopt a very proactive stance when some armed groups decided to reduce the ONUC freedom of movement without directly threatening UN troops, in order to attack the civilian population without ONUC's interference. As a result, ONUC decided to use armed force to preserve its own freedom of movement, even if this was not strictly in line with the mandate of the mission. ${ }^{26}$

Again, between 1992 and 1995, the United Nations Protection Force (UNPROFOR) deployed in former Yugoslavia faced significant difficulties in protecting civilians because it was trying to use armed force only in self-defence. Despite the Secretary-General's claim that the mission was governed by the traditional principles of peacekeeping, ${ }^{27}$ the UNSC authorized the use of armed force to guarantee the freedom of movement of the peacekeepers. ${ }^{28}$ However, the subsequent authorisation to use armed force was limited to responding to threats, ${ }^{29}$ and the mandate proved tragically unable to prevent genocide and other mass atrocities against the civilian population.

Similarly, in 1993, after the failure of two previous missions, the UNSC conferred enforcing powers on the United Nations Operation in Somalia II (UNOSOM II). The mission was tasked with establishing a secure humanitarian environment in Somalia, which was, at that time, in a

24 ONUC was established by SC Res 143 (1960), 14 July 1960.

25 See SC Res. 161 (1961), 21 February 1961; SC Res. 169 (1961), 24 November 1961.

26 See S/5078 (1962), 16 February 1962; G. Abi-Saab, The United Nations Operation in the Congo 1960-1964 (OUP, Oxford, 1978), at 174-176.

27 S/23592, 15 February 1992, 6.

28 SC Res 807 (1993), 19 February 1993, para. 4.

29 SC Res. 836 (1993), 4 June 1993, para. 5. 
prolonged NIAC. ${ }^{30}$ As in relation to $\mathrm{ONUC}$, the creation of this safe environment through the proactive use of armed force was not the direct response to attacks against the members of the mission.

Likewise, the United Nations Assistance Mission for Ruanda (UNAMIR) illustrates the inadequacy of traditional peacekeeping in NIACs. Since the mission was originally tasked with the monitoring of a cease-fire 1993, ${ }^{31}$ it was unable to prevent the genocide of Tutsis in 1994, notwithstanding the attempts of the UNSC to adjust its mandate to include both "act[ing] as an intermediary between the parties" ${ }^{32}$ and taking "action in self-defence against persons or groups who threaten" civilians and UN personnel. ${ }^{33}$ The limitation of the use of armed force to selfdefence rendered the peacekeepers unapt to protect civilians. ${ }^{34}$

These four examples are sufficient to demonstrate that the principles of peacekeeping established under UNEF I were unable to address NIACs where hot hostilities occur. As a result, these same principles evolved and the UNSC decided to apply them very differently from the traditional model.

(C) ROBUST MANDATES AND THE PRINCIPLES OF PEACEKEEPING

\section{(1) The Emergence of the Concept of Robust Mandates}

"Robust mandates" can be defined as "operations where, strictly speaking, use of force [is] authorized beyond self-defence". 35 They are the product of a significant debate that occurred during the 1990s, which focused on the protection of civilians by peacekeeping forces, on the limits of the traditional model, and on the need to reshape the principles of peacekeeping.

Following the dramatic experiences in Somalia, Bosnia, and Rwanda, the UN openly acknowledged the need to focus on a proactive strategy for the protection of civilians. For instance, in 1999, in relation to the United Nations Mission in Sierra Leone (UNAMSIL), the UNSC, "[a]cting under Chapter VII" of the UN Charter, decided that UNAMSIL could "take the necessary action to ensure the security and freedom of movement of its personnel and [...] to afford protection to civilians under imminent threat of physical violence".36 Notwithstanding the failure of UNAMSIL to protect civilians, 37 this shift to more proactive mandates, wherein

30 See SC Res. 814 (1993), 26 March 1993; SC Res. 837 (1993), 6 June 1993. For an evaluation of the peacekeeping experience in Somalia, see R. Murphy, UN Peacekeeping in Lebanon, Somalia and Kosovo: Operational and Legal Issues in Practice (CUP, Cambridge, 2007), at 48-63 and 93-95.

31 SC Res. 872 (1993), 5 October 1993, para. 3.

32 SC Res. 912 (1994), 21 April 1994, para. 8(a).

33 SC Res. 918 (1994), 17 May 1994, para. 4.

34 See the reconstruction offered by the fictional movie directed by M. Caton-Jones, Shooting Dogs (2005).

35 M. Bothe, 'Peacekeeping Forces', in R. Wolfrum (ed.), Max Planck Encyclopedia of Public International Law online, (OUP, Oxford, 2016), para. 19.

36 SC Res. 1270 (1999), 22 October 1999, para. 14.

${ }^{37}$ See S.W. Lyons, 'New Robust Peacekeeping', 112 Proceedings of the ASIL Annual Meeting (2018) 109, at 110 
peacekeepers were explicitly authorized to use force beyond self-defence, has become commonplace today.

As a result, the 2001 Brahimi Report acknowledged that peacekeepers "must be capable of defending themselves, other mission components, and the mission's mandate." 38 The Report went on to affirm that "[r]ules of engagement should be sufficiently robust and not force [UN] contingents to cede the initiative to their attackers". ${ }^{39}$ Accordingly, the expressions "robust peacekeeping missions" became commonplace in the language of international relations as well as in academic literature. ${ }^{40}$

So far, the UNSC has dispatched robust mandates mainly in contexts of NIACs, where the protection of civilians was a particularly difficult task. These mandates can be seen as a necessary step to adjust the UNEF I model, created to deal with inter-State conflicts, to the realities of NIAC. To this end, as it is discussed in the following subsection, since 1999, the UNSC has employed the traditional language of authorisations to the use of armed force under Chapter VII of the UN Charter to protect civilians.41 Nonetheless, at the same time, the UN has maintained that the evolution of UN peacekeeping entails a reshaping — rather than an abjuration — of the traditional principles of peacekeeping, which are still in principle valid and applicable. ${ }^{42}$

Since robust mandates differ from the original model based on the experience of UNEF I and subsequently followed by the UNSC, it is necessary to understand how the basic principles of peacekeeping have been interpreted and adjusted when peacekeepers have been authorized to use armed force beyond self-defence. This is the necessary mid-step before assessing whether these principles, even in light of their reshaping to accommodate robust mandates, are applicable to most recent super-robust mandates.

\section{(2) The Use of Armed Force in Robust Mandates}

With regard to the issue of the use of armed force, as already mentioned, peacekeepers were originally authorized to use armed force in personal self-defence. Without entering the debate of

\footnotetext{
[doi:10.1017/amp.2019.12].

38 Brahimi Report, supra n. 13, at x.

39 Ibid.

40 See, e.g., the discussion in J. Sloan, The Militarisation of Peacekeeping in the Twenty-First Century (Hart, Oxford/Portland, 2001); T. Findlay, The Use of Force in UN Peace Operations (OUP, Oxford, 2002); F. Vacas Fernández, El régimen jurídico del uso de la fuerza por parte de las operacines de mantenimiento de la paz de Naciones Unidas (Marcial Pons, Madrid, 2005); L. Pineschi, 'L'emploi de la force dans les opérations de maintien de la paix des Nations Unies “robustes": conditions et limites juridiques', in M. Arcari and L. Balmond (eds), La sécurité collective entre légalité et défis à la légalité (Giuffrè, Milano, 2008) 139; N. White, 'Peacekeeping or War-fighting?', in N. White and C. Henderson (eds), Research Handbook on International Conflict and Security Law (Edward Elgar, Cheltenham, 2013) 572;.

41 See, e.g., SC Res. 1270 (1999), 22 October 1999, para. 14.

42 See Brahimi Report, supra n. 13, at para. 48. On the ongoing role of the basic principles of peacekeeping in relation to recent mandates, see Tsagourias, supra $\mathrm{n} .1$.
} 
the legal ground of this entitlement, 43 suffice it to note that every person whose life is under threat has the right to self-defence under international law.44 As stated by the Secretary-General in relation to UNEF I, "men engaged in the operation may never take the initiative in the use of armed force, but are entitled to respond with force to an attack with arms".45 However, the concept of personal self-defence has been extended to include also the protection of civilians, in line with the police officers' entitlement to use armed force to protect persons under their responsibility pursuant to international human rights law.46 The Brahimi report employs a wider reference to the use of armed force to "protect the mandate", which means that peacekeepers may use force not only as a response against direct violence, but also to protect civilians. ${ }^{47}$

Furthermore, in recent robust mandates, the UNSC has authorized the use of any means or measures necessary to fulfil the mandate. ${ }^{48}$ These expressions resonate the practice of authorizing enforcement missions under Chapter VII of the UN Charter, where "any necessary means" and "any necessary measure" encompass the possibility to use armed force, as in the cases of the operations in Kuwait and Libya. ${ }^{49}$ However, the UNSC does not invoke directly Article 42 of the UN Charter in relation to these missions. Accordingly, the indication of Chapter VII could also be interpreted as a reference to the power of the UNSC to adopt non-forcible measures to maintain international peace and security under Article 41.

Taking into account the experience of ONUC, UNPROFOR, and other missions, the authorization to take any necessary means and any necessary measure to protect civilians is wide enough to cover the use of armed force in some situations where, prima facie, there is no direct threat against the peacekeepers or the civilians under their responsibility. For instance, the use of armed force to guarantee freedom of movement of peacekeepers is often expressly recognized or is implicit in the notion of "every necessary means" to protect civilians. ${ }^{50}$ However, there is a general understanding that "peacekeeping operations should only use force as a measure of last resort, when other means have failed". ${ }^{51}$

The progressive involvement of peacekeepers in actual hostilities has led the Secretary-General to deal with the applicability of the rules of international humanitarian law to peacekeepers. ${ }^{52}$

43 See the brief discussion in B. Oswald, 'Robust Peacekeeping and Self-Defense', 112 Proceedings of the ASIL Annual Meeting (2018) 117-120 [doi:10.1017/amp.2019.15].

44 See Gill et al. (eds), supra n. 5, at 147.

45 Summary Study, supra n. 16, at para. 179.

46 See, e.g., Art. 2(2)(a) of the ECHR.

47 See Brahimi Report, supra n. 13, at para. 49.

48 See, e.g., SC Res. 1270 (1999), 22 October 1999, para. 14; SC Res. 1975 (2011), 30 March 2011, para. 6; SC Res. 2100 (2013), 25 April 2013, para. 17; SC Res. 2155 (2014), 27 May 2014, para. 4; SC Res. 2295 (2016), 29 June 2016, para. 17; SC Res. 2304 (2016), 12 August 2016, paras. 5 and 10.

49 See SC Res. 678 (1990), 29 November 1990, para. 2; SC Res. 1973 (2011), 17 March 2011, para. 4. See, generally, Pineschi, supra n. 40, at 165-167.

50 See, e.g., SC Res. 1270 (1999), 22 October 1999, para. 14.

51 Trial Chamber, Prosecutor v. Issa Hassan Sesay, Morris Kallon and Augustine Gbao (Case no. SCSL-04-15), Judgement, No. SCSL-04-15-T, 2 March 2009, para 228.

52 See, e.g, R. Kolb, Droit humanitaire et opérations de paix internationales $\left(2^{\text {nd }}\right.$ ed., Bâle, Helbing \& Lichtenhan, 
Taking into account some scholarly suggestions, ${ }^{53}$ in 1999 the Secretary-General adopted the bulletin "Observance by United Nations Forces of International Humanitarian Law", which prescribes the observance of the law of armed conflict by UN troops involved in hostilities, even when they are deployed in the context of a peacekeeping mission. ${ }^{54}$ In the same fashion, the 1994 Convention on the Safety of United Nations and Associated Personnel provides that its legal protection does not apply to peacekeepers who are involved in actual hostilities, ${ }^{55}$ whatever they occur in the framework of self-defence actions and offensive operations. ${ }^{56}$

However, until 2013, robust mandates have interpreted the principle of non-use of armed force as limiting the activities of the peacekeepers to their own protection, the protection of civilians, and the protection of the mandate. The practice of the UNSC, mainly through the invocation of Chapter VII, has also considered covered by this principle other connected operations, such as those launched to guarantee the freedom of movement of the mission. Nonetheless, any decision of peacekeepers to use armed force was framed as defensive.

\section{(3) Consent in Robust Mandates}

Consent has long been considered to be the main legal basis that makes the deployment of peacekeepers lawful. ${ }^{57}$ Traditionally, the UNSC has sought the consent of the internationally recognized governments of the territory(ies) in which a mission was to be dispatched. As a result, the lack of consent of the territorial State in relation to the deployment of a mission can result in a severe impairment to its operability, as demonstrated by the Croatian withdrawal of consent to the presence of UNPROFOR on its own territory, which has led to the replacement of the

2006); A. Segura Serrano, El derecho internacional humanitario y las operaciones de mantenimiento de la paz de Naciones Unidas (Plaza y Valdes, Madrid, 2007); T. Ferraro, 'The Applicability and Application of International Humanitarian Law to Multinational Forces', 95 IRRC (2013) 561-612 [doi:10.1017/S181638311400023X]; E. Nalin, L'applicabilità del diritto internazionale umanitario alle operazioni di peace-keeping delle Nazioni Unite (Editoriale Scientifica, Napoli, 2018).

53 Before the adoption of the Bulletin, this possibility has been discussed e.g. by L. Condorelli, 'Le Statut des forces de l'ONU et le droit international humanitaire', 78 RDI (1995) 881-906.; Emanuelli, Les actions militaires de l'ONU et le droit international humanitaire (Wilson \& Lafleur Itée, Montréal, 1995).

54 ST/SGB/1999/13 (1999), 6 August 1999, Section 1.1. On the bulletin, see L. Condorelli, 'Le azioni dell'ONU e l'applicazione del diritto internazionale umanitario: il bollettino del Segretario generale del 6 agosto 1999', 82 RDI (1999) 1049-1053; P. Benvenuti, 'Le respect du droit international humanitaire par les forces des Nations Unies: La circulaire du Secrétaire Général', 105 RGDIP (2001) 335-372.

55 See Art. 2(2), Convention on the Safety of United Nations and Associated Personnel, 2051 UNTS 363. See, also, Nalin, supra n. 52, at 127-142.

56 On the different rules applicable in law-enforcement operations, see S. Wills, 'Use of Deadly Force by Peacekeepers Operating Outside of Armed Conflict Situations: What Laws Apply?', 40 Human Rights Quarterly (2018) 663-702 [doi:10.1353/hrq.2018.0036].

57 See A. Di Blase, 'The Role of the Host State's Consent with Regard to Non-Coercive Actions by the United Nations', in A. Cassese (ed.), United Nations Peace-Keeping (Sijthoff \& Noordhoff, Alphen aan den Rijn, 1978) 55; Gargiulo, supra n. 5, at 336; Iglesias Velasco, supra n. 6, at 144-145; J. Cardona Llorens, 'Universalismo y regionalismo en el mantenimiento de la paz a inicios del siglo XXI', in Universalismo y Regionalismo a Inicios del Siglo XXI (OAs, Washington, DC, 2010) 47, at 98; Frulli, supra n. 5, at 73; Y. Dinstein, War, Aggression and SelfDefence $\left(6^{\text {th }}\right.$ ed., CUP, Cambridge, 2017), at 356; C. Gray, International Law and the Use of Force (4th $\mathrm{ed}$., OUP, Oxford, 2018), 316; Handerson, supra n. 15, at 195. 
mission. ${ }^{58}$

In relation to robust mandates, the practice of the UNSC has evolved so that today not all the belligerents are required to consent to the deployment of peacekeeping missions. Although the consent of the territorial State(s) is still considered to be crucial, the UNSC has considered it to be politically desirable and appropriate - but not legally mandatory — to request the consent of some armed groups involved in the armed conflict, in order to enhance the success of the mission, ${ }^{59}$ "not out of legal obligation, but rather to ensure the effectiveness of the peacekeeping operation". ${ }^{60}$ On the other hand, the UNSC has decided not to seek the consent of other armed groups considered to be insurmountable obstacles to the reconciliation process, who are usually labelled as "local spoilers" and are often targeted by UN sanctions. ${ }^{61}$ According to the Capstone doctrine, "[u]niversality of consent becomes even less probable in volatile settings, characterized by the presence of armed groups not under the control of any of the parties, or by the presence of other spoilers". ${ }^{62}$

This differential approach regarding the consent of the belligerents involved in a NIAC may be justified under practical reasons. Since robust mandates are deployed in order to support the central government in the reconciliation process, and peacekeepers likely are to fight against local spoilers, it would be unrealistic for the UNSC to seek and obtain the consent of those same armed groups that the mission is supposed to fight.

\section{(4) Neutrality / Impartiality of Robust Mandates}

The evolution faced by the rules on the use of armed force and consent has had a significant impact on the neutral character of the missions, the third principle of peacekeeping. In robust mandates, peacekeepers are no longer considered to be prevented from taking sides in the conflict in every circumstance. Accordingly, the understanding of this principle has evolved to take into account the robustness of some new mandates.

Peacekeepers operating on the basis of robust mandates can employ limited armed force against threats to their security and to the civilians under their protection. Although whether this is sufficient evidence of lack of neutrality is case-specific, the very fact that some of the belligerents are not required to consent to the deployment of the mission runs against the neutral character as envisaged by UNEF I. To solve the conundrum of the ongoing relevance of this principle, mainly three arguments have been offered, all of them switching the attention from neutrality to impartiality.

58 Gray, supra n. 57, at 316.

$59 \quad$ Ibid., at 318.

60 Sesay, Kallon and Gbao case, supra n. 51, at. para. 226.

61 G. Gaja, 'Use of Force Made or Authorized by the United Nations', in C. Tomuschat (ed.), The United Nations at Age Fifty: A Legal Perspective (Brill, Leiden, 1995) 39, at 51; Iglesias Velasco, supra n. 6, at 144-145; Cardona Llorens, supra n. 57, at 98; I. Johnstone, 'Managing Consent in Contemporary Peacekeeping Operations', 18 International Peacekeeping (2011) 168, at 171-172 [doi:10.1080/13533312.2011.546091]; Frulli, supra n. 5, at 72-79.

62 Capstone Doctrine, supra n. 13, at 32. See, also, HIPPO Report, supra n. 13, at para. 127. 
The first argument dilutes the principle so that its actual legal meaning risks being lost. The Brahimi report considers that impartiality means "adherence" of the mission "to the principles of the UN Charter and to the objectives of a mission mandate that is rooted in Charter principles". ${ }^{63}$ This reference to the adherence to the principles of the UN Charter is problematic since its actual meaning is rather obscure: the only possible interpretation is that mandates adopted following the UN rules and goals are per se impartial. However, this interpretation results in confusion between the legality of the mandates in their entirety and their impartiality, which is only one of the principles governing the legality of peacekeeping. Moreover, since non-State belligerents have no means to challenge the mandate because of a lack of adherence to the principles of the Charter, constructing impartiality as adherence to the principles of the Charter is ultimately an exercise of faith in the respect for UN procedures and goals by the UNSC. 64

A second line of argument takes a more practical approach and considers that the neutrality of the mandate is no longer a requirement for the legality of the mission, but rather, the UN should pursue the political goal of dispatching missions that are perceived as impartial by all the relevant stakeholders. ${ }^{65}$ In the case of robust mandates, the missions simply do not have a neutral or impartial nature, as clearly demonstrated by the role they play against some armed groups. However, due to the political nature of the principle at hand, any violation is not a source of illegality for the mandate. Lamentably, this idea conflicts with the well-established belief that the three principles of peacekeeping are relevant for the legality of the missions.

A third and more persuasive argument shifts the focus of this principle from the UN involvement in the conflict to the equal treatment of the parties. As noted by the Capstone Doctrine, whereas in principle peacekeeping forces should have been neutral, that is, they should not been involved in the conflict in any way, recently, the emphasis of the discourse has been on impartiality, that is, dealing without favour or prejudice to any party to the conflict. ${ }^{66}$ Accordingly, peacekeepers "should not condone actions by the parties that violate the undertakings of the peace process or international norms and principles". ${ }^{67}$ More recently, the HIPPO Report concluded that the impartiality of UN missions "should be judged by its determination to respond even-handedly to the actions of different parties based not on who has acted but by the nature of their actions. Missions should protect civilians irrespective of the origin of the threat". ${ }^{6}$

It is possible to conclude, therefore, that the principle of neutrality has been replaced by the principle of impartiality. Accordingly, peacekeepers should protect civilians from any threats,

\footnotetext{
63 Brahimi Report, supra n. 13, at para. 50.

64 For some critical remarks on the Brahim Report's idea of impartiality, see H. Yamashita, "Impartial" Use of Force in United Nations Peacekeeping', 15 International Peacekeeping (2008) 615-630 [doi:10.1080/13533310802396152].

65 Frulli, supra n. 5, at 62.

66 Capstone Doctrine, supra n. 13, p. 33.

67 Sesay, Kallon and Gbao case, supra n. 51, para. 227.

68 HIPPO Report, supra n. 13, para. 126.
} 
irrespective of whether they come from governmental forces or armed groups.

(D) THE CHALLENGES SUPER ROBUST MANDATES POSE TO THE PRINCIPLES OF PEACEKEEPING, WITH SPECIFIC REFERENCE TO THE USE OF ARMED FORCE

\section{(1) Preliminary Remarks}

This Section explores the degree of armed force authorized by the UNSC in recent super-robust mandates which show an unprecedented offensive stance. The prototype of these mandates is MONUSCO after 2013, when the UNSC created an offensive unit (the Intervention Brigade) within the mission and tasked it with neutralizing certain armed groups in the Democratic Republic of the Congo (DRC). Moreover, three other recent peacekeeping missions, MINUSMA, MINUSCA, and UNMISS, involve the use of armed force beyond what had been so far authorized in relation to peacekeeping missions. The degree of armed force that peacekeepers can employ in these missions plummeted after the creation of the Intervention Brigade within MONUSCO, consolidating a trend towards super-robust mandates. ${ }^{69}$ All these mandates are therefore problematic in relation to the compatibility between the armed force authorized by the UNSC and the principles of peacekeeping as crystallized in UN practice at the beginning of the new millennium.

\section{(2) The Use of Armed Force by MONUSCO}

The United Nations Organization Mission in the Democratic Republic of the Congo (MONUC) was established in 1999 by the UNSC Resolution 1279, which authorized to use armed force only in self-defence. ${ }^{70}$ However, since then, the UNSC has increased the degree of armed force that peacekeepers were authorized to employ, following a progressive intensification of the hostilities against civilians and against the mission. In 2000, the UNSC authorized the mission to take the necessary action to protect UN personnel, ensure their security and freedom of movement, and protect civilians under imminent threat of physical violence. ${ }^{71}$ Moreover, in 2003 , the UNSC further authorized MONUC to take all necessary measures to fulfil its mandate, ${ }^{72}$ while, in 2008 , the UNSC stressed that MONUC was authorized to use all necessary means ${ }^{73}$ inter alia to deter any attempt at the use of force to threaten the peace process, "undertaking all necessary operations to prevent attacks on civilians and disrupt the military capability of illegal armed

69 On the precedential value of the Intervention Brigade, see D. Kearney, 'The Slippery Slope of UN Peacekeeping: Offensive Peacekeeping in Congo and Beyond', 19 MPUNYB (2016) 100-141 [doi:10.1163/18757413$00190005]$.

$70 \quad$ SC Res. 1279 (1999), 30 November 1999, para. 5.

71 SC Res. 1291 (2000), 24 February 2000, para. 8.

72 SC Res. 1493 (2003), 28 July 2003, paras. 25-26.

73 SC Res. 1856 (2008), 22 December 2008, para. 5. 
groups". ${ }^{74}$ When, in 2010, MONUC was renamed MONUSCO, ${ }^{75}$ its mandate was already significantly robust and it involved the use of armed force beyond self-defence. ${ }^{76}$

Nonetheless, due to the ongoing threats to civilians in the eastern regions of DRC and to peacekeepers deployed therein, in 2013, upon recommendation of the Secretary-General, ${ }^{77}$ the UNSC created the Intervention Brigade within the MONUSCO, which was tasked with offensive combat functions. According to Resolution 2098 (2013), the Intervention Brigade consisted in three infantry battalions, one artillery and one Special force and Reconnaissance company with the responsibility of neutralizing armed groups and the objective of contributing to reducing the threat posed by them to State authority and civilians. ${ }^{78}$ The UNSC described the IB's mandate to neutralize armed groups as comprising "support of the authorities of the DRC [...] to carry out targeted offensive operations [...] either unilaterally or jointly with [the DRC army], in a robust, highly mobile and versatile manner". ${ }^{79}$ Although the UNSC affirmed that the creation of the Intervention Brigade was intended "on an exceptional basis and without creating a precedent or any prejudice to the agreed principles of peacekeeping", ${ }^{80}$ the existence of such a unit has been confirmed between 2014 and 2019. ${ }^{81}$ Despite the UNSC's reiteration that the Intervention Brigade should pursue a rapid exit strategy to return its responsibilities to the DRC government, ${ }^{82}$ the Secretary-General acknowledged slow progress by the DRC to facilitate it. ${ }^{83}$

The UNSC's decision to task MONUSCO with neutralizing armed groups through robust military operations has raised criticism regarding MONUSCO's actual compliance with the basic principles of peacekeeping. ${ }^{84}$ The answer to this question needs to take into account seven years

$74 \quad$ Ibid. para. $3(\mathrm{~d})$.

75 SC Res 1925 (2010), 28 May 2010.

76 For an account of the degree of force employed by MONUC in that period, see R. Murphy, 'UN Peacekeeping in the Democratic Republic of the Congo and the Protection of Civilians', 21 JCSL (2016) 209, at 220-222 [doi:10.1093/jesl/krv030].

77 S/2013/119, 27 February 2013, paras. 60-64.

78 SC Res. 2098 (2013), 28 March 2013, para. 9.

79 Ibid. para. $12(\mathrm{~b})$.

$80 \quad$ Ibid. para. 9.

81 SC Res. 2147 (2014), 28 March 2014, para. 1; SC Res. 2211 (2015), 26 March 2015, para. 1; SC Res. 2277 (2016), 30 March 2016, para. 24; SC Res. 2348 (2017), 31 March 2017, para. 26; SC Res. 2409 (2018), 27 March 2018 , para. 29; SC Res. 2502 (2019), 19 December 2019, para. 22.

82 SC Res. 2098 (2013), 28 March 2013, para. 10; SC Res. 2147 (2014), 28 March 2014, para. 3; SC Res. 2211 (2015), 26 March 2015, paras. 40-41; SC Res. 2277 (2016), 30 March 2016, paras. 47-48; SC Res. 2409 (2018), 27 March 2018, paras. 56 and 59 (IV); SC Res. 2502 (2019), 19 December 2019, paras. 46-48.

${ }_{83}$ See e.g. S/2014/450, 30 June 2014, para. 89; S/2015/172, 10 March 2015, para. 63; S/2016/233, 9 March 2016, para. 74; S/2016/579, 28 June 2016, para. 77.

84 See e.g. P. Fet, 'Tudo de novo no front: MONUSCO, uma nova era nas peacekeeping operations?', 10 Revista de Dereito International (2013) 169-183 [doi:10.5102/rdi.v10i2.2720]; M. Longobardo and F. Violi, 'Quo vadis peacekeeping? La compatibilità dell' Intervention Brigade in Congo con i principi regolanti le operazioni di pace alla prova dei fatti', 70 Comunità Internazionale (2015) 245-272; O. Spijkers, 'The Evolution of United Nations Peacekeeping in the Congo From ONUC, to MONUC, to MONUSCO and its Force Intervention Brigade', 19 Journal of International Peacekeeping (2015) 88-117 [doi:10.1163/18754112-01902004]; D.M. Tull, 'The Limits and Unintended Consequences of UN Peace Enforcement: The Force Intervention Brigade in the DR Congo', 25 International Peacekeeping (2018) 167-190 [doi:10.1080/13533312.2017.1360139]. 
of practice, where the Intervention Brigade and the entire MONUSCO have acted in a very proactive way to deter and respond to attacks by armed groups.

In 2015, I affirmed that the Intervention Brigade per se did not increase drastically the force employed by the already significantly robust MONUSCO, but instead, it appeared as reorganization in one specific unit of those military tasks that were already performed by MONUSCO. ${ }^{85}$ However, this conclusion - which was tributary to a naïve trust in the UNSC's pledge that the mission was created on exceptional basis - is no longer correct after seven years of activity of the IB. Indeed, the proactive involvement of this unit and of other military components of MONUSCO in the hostilities against armed groups in DRC is demonstrated by a significant deployment of means and methods of warfare. For instance, the Secretary-General acknowledged MONUSCO's participation in actual military operations involving the employment of ground troops, attack helicopters, and artillery fire. ${ }^{86}$

Such unprecedented and reiterated involvement in the hostilities unequivocally demonstrates that the mission cannot be considered neutral at all, since it is fighting alongside the government and against some of the belligerents involved in the armed conflict in DRC. ${ }^{87}$ The mission cannot even be considered to be impartial under the most recent understating of this principle, since it is tasked to target only some belligerents. Accordingly, MONUSCO should be considered a party to the ongoing conflict in $\mathrm{DRC},{ }^{88}$ and as such, should apply international humanitarian law.89 The HIPPO Report, envisaging this possibility, expressed serious concerns regarding the impact of such an extraordinarily robust mission on the very concept of peacekeeping. ${ }^{90}$

In conclusion, the degree of armed force authorized by the UNSC and actually employed by MONUSCO is unprecedented and goes well beyond concepts such as personal self-defence, defence of civilians, defence of the mandate, and others previously employed by the UNSC. Accordingly, it is impossible to reconcile MONUSCO and the Intervention Brigade with the principles of peacekeeping, even taking into account the evolution of their interpretation related to robust mandates.

85 Longobardo and Violi, supra n. 84, at 252-254.

86 See e.g. S/2013/581, 30 September 2013, para. 37; S/2013/757, 17 December 2013, para. 40; S/2014/157, 5 March 2014, para. 39; S/2014/450, 30 June 2014, para. 54; S/2014/698, 25 September 2014, paras. 55 -57; S/2015/172, 10 March 2015, paras. 35-36 and 38-39; S/2015/486, 26 June 2015, paras. 18-19 and 43; S/2016/233, 9 March 2016, paras. 24, 27, 29, and 41; S/2016/579, 28 June 2016, paras. 26, 32, and 33; S/2017/206, 10 March 2017, para. 59; S/2017/826, 29 September 2017, para. 42.

87 Longobardo and Violi, supra n. 84, at 256-257; Spijkers, supra n. 84, at 104.

88 Longobardo and Violi, supra n. 84, at 257-265; Nalin, supra n. 52, at 116; B. Maganza, 'From Peacekeepers to Parties to the Conflict: An IHL's Appraisal of the Role of UN Peace Operations in NIACs', 25 JCSL (2020, online advance access) 1 , at 14-15 [hdoi:10.1093/jcsl/krz032].

89 See, generally, D. Whittle, 'Peacekeeping in Conflict: The Intervention Brigade, MONUSCO, and the Application of International Humanitarian Law to United Nations Forces', 46 Georgetown JIL (2015) 837-875.

90 HIPPO Report, supra n. 13, at para. 122. 
(3) The Use of Armed Force by MINUSMA

The UNSC has provided MINUSMA with a robust mandate since its creation in 2013, when MINUSMA has been authorized to use all necessary means to carry out all the components of its mandate, rather than the protection of civilians only. ${ }^{91}$ Since 2016, the UNSC has tasked MINUSMA with a super-robust mandate as demonstrated by some additional textual elements embodied in the relevant resolutions. On a number of occasions, the UNSC requested MINUSMA to "achieve its more proactive and robust posture to carry out its mandate" 92 and to "carry out its mandate with a proactive, robust, flexible and agile posture". ${ }^{93}$ Moreover, the UNSC has emphasized that MINUSMA should not only respond and prevent attacks against civilians, but also should "take active steps to anticipate" them. ${ }^{94}$ The UNSC tasked MINUSMA with actions "in support of the Malian authorities [...] to anticipate, deter and counter threats, including asymmetric threats, and to take robust and active steps to protect civilians [...] engaging in direct operations". ${ }^{55}$ Moreover, MINUSMA has to act in "active defence of its mandate, to anticipate and deter threats and to take robust and active steps to counter asymmetric attacks [...], to ensure prompt and effective responses to threats of violence against civilians and to prevent a return of armed elements to those areas, engaging in direct operation". ${ }^{96}$ In 2019 , the UNSC commended MINUSMA's efforts "to adopt a more robust posture over the past months as well as the intensification of the frequency and scale of its operations." 97 This terminology reinforces the offensive nature on the mission.

Contrary to any other antecedent practice, MINUSMA is openly deployed as an instrument to combat international terrorism. For instance, the UNSC expressed its concern over "the expansion of terrorist and other criminal activities into central and southern Mali"98 and over "the transnational dimension of the terrorist threat in the Sahel region". ${ }^{99}$ Moreover, in furtherance of MINUSMA's implementation of the Agreement on Peace and Reconciliation in Mali, ${ }^{100}$ the UNSC has drawn attention to the need "to forestall attempts by terrorist groups to derail the implementation of the Agreement". ${ }^{101}$

91 SC Res. 2100 (2013), 25 April 2013, para. 17; SC Res. 2164 (2014), 25 June 2014, para. 12; SC Res. 2227 (2015), 29 June 2015, para. 12; SC Res. 2295 (2016), 29 June 2016, para. 17; SC Res. 2364 (2017), 29 June 2017, pa ra. 18; SC Res. 2480 (2019), 28 June 2019, para. 19.

92 SC Res. 2295 (2016), 29 June 2016, para. 18; SC Res. 2364 (2017), 29 June 2017, para. 19.

93 SC Res. 2480 (2019), 28 June 2019, para. 22.

94 See, e.g., SC Res. 2295 (2016), 29 June 2016, para. 19(c)(2); SC Res. 2480 (2019), 28 June 2019, para. 28(c)(2).

95 SC Res. 2295 (2016), 29 June 2016, para. 19(c)(ii) (emphasis added); SC Res. 2364 (2017), 29 June 2017, para. $20(\mathrm{c})(2)$ (emphasis added).

96 SC Res. 2295 (2016), 29 June 2016, para. 20; SC Res. 2364 (2017), 29 June 2017, para. 20(c)(2) (emphasis added).

97 SC Res. 2480 (2019), 28 June 2019, preamble (emphases added).

98 SC Res. 2295 (2016), 29 June 2016, preamble; SC Res. 2364 (2017), 29 June 2017, preamble.

99 SC Res. 2295 (2016), 29 June 2016, preamble; SC Res. 2364 (2017), 29 June 2017, preamble. See also SC Res. 2480 (2019), 28 June 2019, preamble.

100 SC Res. 2295 (2016), 29 June 2016, para. 16; SC Res. 2364 (2017), 29 June 2017, para. 17.

101 SC Res. 2295 (2016), 29 June 2016, preamble; SC Res. 2364 (2017), 29 June 2017, preamble. 
In addition, the UNSC has labelled some of the armed groups involved in the armed conflicts in the region as terrorist groups. For instance, the UNSC made a distinction between good armed groups and terrorist armed groups, referring to "the primary responsibility of the Government of Mali, the Plateforme and Coordination armed groups to accelerate the implementation of the Agreement in order to [...] forestall attempts by terrorist groups". ${ }^{102}$ The same resolutions list some belligerents as terrorist groups ${ }^{103}$ and condemn their operations against Malian armed forces as terrorist attacks. ${ }^{104}$

The employment of peacekeepers to combat terrorism is quite a novelty in international law since, normally, States are required to combat terrorism through law-enforcement operations conducted at the national level. The issue here is not whether the relevant armed groups can be characterized as "terrorist groups" under other areas of international law, but whether doing so in the context of a peacekeeping operation is in line with the principles of peacekeeping. These references to terrorism are not a common occurrence in the mandate of peacekeeping operations, but instead, they characterize the mandate of MINUSMA alone. The word "terrorism", as such, is commonly employed in a sense that lacks impartiality, and involves a legal and ethical negative judgment ${ }^{105}$ over some of the belligerents involved in the conflict. Indeed, the stigma attached to the expression "terrorist" is at the basis of the fact that international humanitarian law does not recognize terrorism as a status of individuals involved in hostilities, but rather, prohibits acts aiming at spreading terror among the population. ${ }^{106}$

MINUSMA's mandate is a precedent conflicting with the HIPPO Report, which emphasized that "UN peacekeeping missions, due to their composition and character, are not suited to engage in military counter-terrorism operations. They lack the specific equipment, intelligence, logistics, capabilities and specialized military preparation required". ${ }^{107}$ The Secretary-General also stressed that "a robust peacekeeping mandate does not equal a counter-terrorist mandate", ${ }^{108}$ while Uruguay noted that "peacekeeping operations, owing to their composition and character, are not suited to engage in military counter-terrorism operations." ${ }^{109}$ Likewise, most scholars have criticized the UNSC for having created MINUSMA as an instrument to conduct militarily counterterrorism operations. ${ }^{110}$ Accordingly, it is possible to conclude that, by embodying

102 SC Res. 2295 (2016), 29 June 2016, preamble; SC Res. 2364 (2017), 29 June 2017, preamble.

103 SC Res. 2295 (2016), 29 June 2016, preamble; SC Res. 2364 (2017), 29 June 2017, preamble.

104 SC Res. 2295 (2016), 29 June 2016, preamble; SC Res. 2364 (2017), 29 June 2017, preamble; SC Res. 2480 (2019), 28 June 2019, preamble.

105 See S. Nathanson, Terrorism and the Ethics of War (CUP, Cambridge, 2010), at 11-23; C. Wellman, Terrorism and Counterterrorism: A Moral Assessment (Springer, Dordrecht, 2013), at 6.

106 See M. Pertile, 'Fighting Terror within the Law? Terrorism, Counterterrorism and Military Occupations', in F. Pocar, M. Pedrazzi and M. Frulli (eds), War Crimes and the Conduct of Hostilities (Edward Elgar, Cheltenham, 2013) 276.

107 HIPPO Report, supra n. 13, at para. 116. See, also, Gill et al. (eds), supra n. 5, at 146.

108 UN Press Release, “Calling Additional Peacekeepers "Force Multipliers" in Mali, Secretary-General Urges New Contributions to Reinforce Mission's Protection Mandate, 23 May 2017.

109 S/PV.7727, 29 June 2016, 3.

110 See J. Karlsrud, 'The UN at War: Examining the Consequences of Peace-Enforcement Mandates for the UN 
counter-terrorism language and tasks in the MINUSMA's mandate, the UNSC has renounced the impartiality of the mission, creating a dangerous shortcut between different areas of intervention of the UNSC. ${ }^{111}$

It is worth noting that Mali has requested the UNSC to create an offensive unit on the model of the Intervention Brigade deployed in DRC, ${ }^{112}$ which clearly had a precedential value notwithstanding the reassurances offered by the UNSC. ${ }^{113}$ The UNSC, however, decided to authorize the French troops already deployed in Mali in support of MINUSMA, ${ }^{114}$ to try to keep a formal separation between peacekeepers (MINUSMA) and belligerents (France). ${ }^{115}$

\section{(4) The Use of Armed Force by MINUSCA}

When the UNSC created MINUSCA in 2014, the mission was authorized to "take all necessary means" to carry out is mandate, primarily concerned with the protection of civilians. ${ }^{116}$ This robust mandate was subsequently reinforced when the UNSC clarified that MINUSCA, "in support of the CAR authorities, [has] to take active steps to anticipate, deter and effectively respond to serious and credible threats to the civilian population". ${ }^{117}$ The UNSC went on to affirm that "MINUSCA's strategic objective is to support the creation of conditions conducive to the sustainable reduction of the presence of, and threat posed by, armed groups through a comprehensive approach and proactive and robust posture without prejudice to the basic principles of peacekeeping". ${ }^{118}$

Notwithstanding the invocation of the basic principles of peacekeeping, in fact, MINUSCA has been significantly involved in hostilities on the side of the government. For instance, it assisted the Central African government to disarm and arrest people involved in organized crime in the framework of an operation where live fire was exchanged and a number of peacekeepers

Peacekeeping Operations in the CAR, the DRC and Mali', 36 TWQ (2015) 40, at $45-47$ [doi:10.1080/01436597.2015.976016]; M. Sossai, 'Il mandato delle operazioni di peacekeeping e il contrasto a gruppi terroristici', in I. Caracciolo and F. Montuoro (eds), L'evoluzione del peacekeeping: il ruolo dell'Italia (Giappichelli, Torino, 2017) 89; J. Karlsrud, “Towards UN Counter-Terrorism Operations?", 38 TWQ (2017) 1215-1231 [doi:10.1080/01436597.2016.1268907].

111 Gilder, supra n. 3, At 64; See L. Attree and J. Street, 'U.N. Peace Operations Should Get Off the Counter-

Terror Bandwagon', Just Security, 4 September 2018.

112 S/PV.7355, 6 January 2015, 7.

113 See Maganza, supra n. 88, at 18.

114 See, e.g., SC Res. 2295 (2016), 29 June 2016, para. 35.

115 See the very critical remarks by K. Bannelier and T. Christakis, 'Under the UN Security Council's Watchful Eyes: Military Intervention by Invitation in the Malian Conflict', 26 LJIL (2013) 855, at 870-873 [doi:10.1017/S0922156513000447].

116 SC Res. 2149 (2014), 10 April 2014, paras. 30 and 30(a). See, also, SC Res. 2217 (2015), 28 April 2015, paras. 31-32; SC Res. 2281 (2016), 26 April 2016, para. 2; SC Res. 2301 (2016), 26 July 2016, paras. 32-33; SC Res. 2387 (2017), 15 November 2017, paras. 41-42; SC Res. 2448 (2018), 13 December 2018, paras. 38-39; SC Res. 2499 (2019),

15 November 2019, paras. 31-32.

117 See, e.g., SC Res. 2499 (2019), 15 November 2019, para. 32(a)(ii).

118 SC Res. 2387 (2017), 15 November 2017, para. 39; SC Res. 2448 (2018), 13 December 2018, para. 36; SC Res. 2499 (2019), 15 November 2019, para. 29. 
were killed. ${ }^{119}$ The use of armed force by MINUSCA in this situation is not justified in self-defence or in defence of civilians, but rather, it was grounded in the MISUSCA's broad authorization to detain enemy fighters and criminals, ${ }^{120}$ which is unusual for a peacekeeping force. ${ }^{121}$

More significantly, in 2017 MINUSCA used its armed helicopters to engage members of armed groups as they attempted to infiltrate Bambari in violation of a previously communicated line, ${ }^{122}$ even in the absence of any actual attacks. ${ }^{123}$ The very commander of the operation acknowledged that this episode put under significant strains the principle of peacekeeping, by affirming that the operation "succeeded because we bent various administrative rules, challenged some limiting agreements with troops and changed morale where the use of force was involved", ${ }^{124}$ and by "apologizing for perhaps bypassing some of the rules". ${ }^{125}$ On other similar occasions, MINUSCA has demonstrated this proactive stance to the use of armed force, taking part in several offensive operations alongside the Central African government. ${ }^{126}$

Accordingly, on the basis of the anticipatory nature of the mandate of MINUSCA and of its open support of the Central African government in law-enforcement activities and hostilities against armed groups, the impartiality of this mission should be questioned. ${ }^{127}$ Moreover, due to the level of hostilities in which MINUSCA is currently involved, it is possible to conclude that the MISSION has become a party in the local armed conflict. ${ }^{128}$

Furthermore, as in relation to MINUSMA, it is possible to argue that the mandate of MINUSCA and its offensive stance is a consequence of the MONUSCO's precedent. ${ }^{129}$ The UN Independent Expert on the situation of human rights in the Central African Republic called for the deployment of a mission tasked with the neutralization of armed groups, ${ }^{130}$ thus echoing the mandate of the IB. Moreover, the UNSC stressed that the authorization of a very proactive use of armed force by MINUSCA is "without prejudice to the basic principles of peacekeeping", ${ }^{131}$ as it was in relation to the IB, ${ }^{132}$ and emphasized that the unprecedented detention powers

$119 \mathrm{~S} / 2018 / 611,18$ June 2018, paras. 16-17.

120 See, e.g., SC Res. 2387 (2017), 15 November 2017, para. 43.

121 See É. Vanspranghe, 'Advancing the Rule of Law through Executive Measures: The Case of MINUSCA', 9 GoJIL (2019) 331-365.

$122 \mathrm{~S} / 2017 / 473,2$ June 2017, para. 11.

123 See also T. Ruys, L. Ferro and C.V. Maelen, 'Digest of State Practice: 1 January-30 June 2017', 4 JUF IL

(2017) 371, at 383 [doi:10.1080/20531702.2017.1385347].

124 S/PV.7947, 23 May 2017, 8.

125 Ibid., at 9.

126 See A. Gilder, 'Human Security and the Stabilization Mandate of MINUSCA', 27 International Peacekeeping (2020, online advance access) 1, at 15-16 [doi:10.1080/13533312.2020.1733423].

127 Ibid., at 24.

128 See P. Labuda, 'The UN Goes to War in the Central African Republic: What Are the Limits of Peacekeeping', Just Security, 23 March 2017; Maganza, supra n. 88, at 19-20.

129 Ibid., at 18; Gilder, supra n. 126, at 16.

130 UN Expert Calls for Calm, Protection of Civilians in Central African Republic, 3 May 2018.

131 SC Res. 2387 (2017), 15 November 2017, para. 39; SC Res. 2448 (2018), 13 December 2018, para. 36; SC Res. 2499 (2019), 15 November 2019, para. 29.

132 See, e.g., SC Res. 2098 (2013), 28 March 2013, para. 9. 
attributed to MINUSCA are bestowed "on an exceptional basis and without creating a precedent and without prejudice to the agreed principles of peacekeeping operations" 133 - again, using exactly the same wording employed to create the IB. ${ }^{134}$

\section{(5) The Use of Armed Force by UNMISS}

Since 2016, UNMISS has been characterized as a robust mission, where the peacekeepers were authorized to "use all necessary means" to achieve the goals of the mission. 135 The main aim of UNMISS is the protection of civilians, ${ }^{136}$ in light of the very dangerous and volatile situations of South Sudan, still torn by a brutal NIAC. 137 The UN has therefore considered necessary a very robust and proactive approach to the use of armed force. ${ }^{138}$

However, a number of attacks from armed groups against UNMISS personnel and facilities has significantly hampered the effective protection of civilians in South Sudan, limiting the action of the mission to the defence of some civilians protection sites established by UNMISS. ${ }^{139}$ In order to allow UNMISS to carry out its mandate also outside these locations as well and to respond against the armed groups' attacks, in 2016, the UNSC created a specific unit within UNMISS, called the Regional Protection Force (RPF). This unit was established under pressure of the main troop-contributing States, which were worried about the safety of their personnel. ${ }^{140}$ According to its mandate, the RPF must use "all necessary means, including undertaking robust action", to achieve "safe and free movement" and to engage "any actor that is credibly found to be preparing attacks, or engages in attacks" against civilians and UN personnel. ${ }^{141}$ After some initial difficulties in creating the RPF, ${ }^{142}$ this unit was deployed and its mandate was renewed in 2018 and 2019, with a wider territorial scope, and the authorization to undertake "robust action where necessary". ${ }^{143}$ In relation to the equipment available for the RPF, the Secretary-General has confirmed that the unit comprises also attack helicopters and one unmanned aerial vehicle unit. ${ }^{144}$

The creation of such a super-robust unit, which is reminiscent of the Intervention Brigade of MONUSCO, is considered an unprecedented step towards further robustness of peacekeeping missions, ${ }^{145}$ and for this reason, its deployment has been initially opposed by the government of

133 See, e.g., SC Res. 2387 (2017), 15 November 2017, para. 43.

134 See, e.g., SC Res. 2098 (2013), 28 March 2013, para 9. See, also, Vanspranghe, supra n. 121, at 338.

135 See SC Res. 2327 (2016), 16 December 2016, para. 7; SC Res. 2392 (2017), 14 December 2017, para. 1; SC Res. 2406 (2018), 15 March 2018, para. 7; SC Res. 2459 (2019), SC Res. 2459 (2019), 15 March 2019, para. 7.

136 SC Res. 2327 (2016), 16 December 2016, para. 7(a); SC Res. 2406 (2018), 15 March 2018, para. 7(a); SC Res. 2459 (2019), 15 March 2019, para. 7(a).

137 See UNMISS, OHCHR, Indiscriminate Attacks Against Civilians in Southern Unity, April - May 2018.

138 See, e.g., S/2018/143, 20 February 2018, paras. 10-20.

139 Ibid., at para. 15.

$140 \mathrm{~S} / 2018 / 143,20$ February 2018, para. 19.

141 SC Res. 2327 (2016), 16 December 2016, para 9. (emphasis added).

142 See S/2017/224, 16 March 2017, para. 49.

143 SC Res. 2406 (2018), 15 March 2018, para. 9; SC Res. 2459 (2019), 15 March 2019, para. 10.

$144 \mathrm{~S} / 2018 / 143,20$ February 2018, para. 19.

145 See R. Murphy, 'The United Nations Mission in South Sudan and the Protection of Civilians', 22 JCSL (2017) 
South Sudan and some members of the UNSC. ${ }^{146}$ Moreover, the active role in the hostilities of the RPF, well beyond personal self-defence or defence of the civilians, along with the political pressures of the UNSC against the government to accept the unit, raise concerns regarding the impartiality of the entire mission. ${ }^{147}$

Accordingly, at the moment, the UNSC has deployed in South Sudan an already robust mission with the task to protect civilians from attacks of armed groups, and a specific superrobust unit within that mission to protect the entire UNMISS from attacks and to guarantee the mission freedom of movement. It seems that the protectors of civilians need some protectors themselves, and that the latter have been equipped and instructed to act as proactive hostile parties rather than as peacekeepers.

\section{(6) Interim Conclusions}

From the overview of the practice concerning MONUSCO, MINUSMA, MINUSCA, and UNMISS, it is possible to conclude that these missions are not in line with the basic principles of peacekeeping. However broadly one may interpret these principles in light of the practice developed by robust mandates, the new mandates developed after the adoption of the Intervention Brigade represents a qualitative leap that it is impossible to reconcile with the common understanding of peacekeeping. Whereas in robust mandates the use of armed force is incidental and functional to the protection of civilians rather than the main scope of the mission, ${ }^{148}$ offensive units such as the Intervention Brigade are primarily tasked with the neutralization of armed groups. Accordingly, it is not possible to reconcile these super-robust missions with the robust mandates that have emerged between the " 90 s and the first decade of the new millennium.

(E) ARE SUPER ROBUST MANDATES STILL PEACEKEEPING OPERATIONS OR SHOULD THEY BE CLASSIFIED DIFFERENTLY?

Since some features of MONUSCO, MINUSMA, MINUSCA, and UNMISS are not in line with the basic principles of peacekeeping, it is worth investigating whether super-robust missions dispatched after 2013 should be considered outside the notion of peacekeeping. In particular, this Section explores whether they could be considered authorizations to the use of armed force under Chapter VII or UNSC's interventions by invitation of the host State.

The boundaries of categories of operations under the UNSC's powers are not very well-defined

367 , at 385 [doi:10.1093/jesl/krx016].

146 Ibid., at 385-387. See, also, Gray, supra n. 57, at 320.

147 See J. Hansohm and Z. Yihdego, 'The South Sudan Crisis: Legal Implications and Responses of the International Community', 1 Ethiopian YBIL (2016) 223, at 233-234 [doi:10.1007/978-3-319-55898-1_10].

148 Tsagourias, supra n. 1, at 471-472; N. Ronzitti, Diritto internazionale dei conflitti armati (6 ${ }^{\text {th }}$ ed., Giappichelli, Torino, 2017), at 72 . 
since the use of armed force by the UNSC is often based on practice rather than on written law. ${ }^{149}$ The original design of the UN Charter involved the creation of a UN army at disposal of the UNSC, through agreements between the UNSC and contributing States that, in fact, have never been concluded. This army would have been employed by the UNSC to exercise its responsibility under Article 42 to "take such action by air, sea, or land forces as may be necessary to maintain or restore international peace and security". Since it is impossible to exercise the powers under Article 42 in the absence of these special agreements, the UNSC has circumvented the problem by authorizing States to use armed force, rather than by using armed force itself, as in the cases of Kuwait in 1990 and Libya in 2011.150 This practice has instigated a significant legal debate on the legal basis of these authorizations adopted by the UNSC. 151 The two main views followed by scholars are that either authorizations of the use of armed force emerged in State practice in the context of Chapter VII, ${ }^{152}$ or are linked directly to Article 42 powers (alone or in conjunction with other provisions of the UN Charter). ${ }^{153}$ Although Article 42 operations and authorizations to the use of armed force are in principle different because the former should be conducted directly by $\mathrm{UNSC}_{,}{ }^{154}$ there is limited opposition on the legality of the authorization of the use of armed force

149 This variety has led scholars to try to systematize them. One author envisages three different kinds of operations under the UNSC egis: peacekeeping operations, peace enforcement operations (here referred to as "robust mandates"), and purely enforcement operations (T. Gill, 'Enforcement and Peace Enforcement Operations', in Gill and Fleck (eds), supra n. 9, at 95). Another scholar classifies UNSC's operations in four groups: traditional peacekeeping, robust peacekeeping, peace enforcement, and Chapter VII enforcement (P.I. Labuda, 'Peacekeeping and Peace Enforcement', in Wolfrum (ed.), supra n. 35, at paras. 35-36). These partitions run contrary the aforementioned UNSC's pledge that robust and super-robust mandates are all based on the principles of peacekeeping. Moreover, I am reluctant to employ the expression "peace enforcement" to avoid confusion: whereas "peace enforcement" is used by some authors in relation to robust peacekeeping missions (e.g., ibid.; F. Salerno, Diritto internazionale (4th ed., Cedam, Padova, 2017), at 256; E. Cannizzaro, Diritto internazionale (4 $4^{\text {th }}$ ed., Giappichelli, Torino, 2018), at 78-79), some UN documents employ peace enforcement as synonymous with authorizations of the use of force similar to Kuwait in 1990 and in Libya in 2011 (e.g., Capstone Doctrine, supra n. 13, at 34).

150 For an overview on other relevant instances of state practice, see P. Gargiulo, 'Sicurezza Collettiva', Enciclopedia del Diritto, Annali IX (2015) 880, at 944-948.

151 See, e.g., D. Sarooshi, The United Nations and the Development of Collective Security (OUP, Oxford, 1999); N. Blokker, 'Is the Authorization Authorized? Powers and Practice of the UN Security Council to Authorize the Use of Force by "Coalitions of the Able and Willing", 11 EJIL (2000) 541-468 [doi:10.1093/ejil/11.3.541]; Picone, supra n. 8; L.-A. Sicilianos, 'Entre multilatéralisme et unilatéralisme: l'autorisation par le Conseil de sécurité de recourir à la

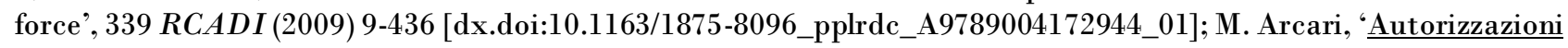
all'uso della forza [dir. int.]', Treccani Online (2014), para. 2.

152 See e.g. G. Gaja, 'Il Consiglio di sicurezza di fronte all'occupazione del Kuwait: il significato di una autorizzazione', 73 RDI (1990) 696, at 697; Sicilianos, supra n. 151, at 165-166; B. Conforti and C. Focarelli, The Law and Practice of the United Nations (5 ${ }^{\text {th }}$ ed., Brill, Leiden, 2016), at 311-12; Dinstein, supra n. 57, at 359; Henderson, supra n. 15, at 112-113.

153 See, for different formulations, R. Higgins, Problems and Process: International Law and How We Use It (OUP, Oxford, 1994), at 266; E. de Wet, The Chapter VII Powers of the United Nations Security Council (Hart, Oxford/Portland, 2004), at 260-261; T. Gazzini, The Changing Rules on the Use of Force in International Law (MUP, Manchester, 2005), at 55-56; U. Villani, L'ONU e la crisi del Golfo (Cacucci, Bari, 2005), at 84; O. Corten, The Law against War (Hart, Oxford/Portland, 2010), at 315-316; N. Krisch, 'Article 42', in B. Simma et al. (eds), The Charter of the United Nations: A Commentary (3 ${ }^{\text {rd }}$ ed., OUP, Oxford, 2012) 1330, at 1337; White, supra n. 40, at 574; Higgins et al, supra n. 6, at 1002-1003; J. Crawford, Brownlie's Principles of Public International Law (9 ${ }^{\text {th }}$ ed., OUP, Oxford, 2019), at 739-740.

154 See Gaja, supra n. 152, at 697; Picone, supra n. 8, at 11-33; Gargiulo, supra n. 150, at 948. However, the lack 
in the context of Chapter VII, at least in principle. ${ }^{155}$ As affirmed by the International Court of Justice, "[i]t cannot be said that the Charter has left the Security Council impotent in the face of an emergency situation when agreements under Article 43 have not been concluded". ${ }^{156}$

Since this expression "authorization to take all necessary means" is embodied in most robust mandates, it could be possible to consider robust and super-robust mandates as authorizations of the use of armed force. However, there are some problems in relation to this characterization. First, super-robust missions, as every peacekeeping operation, are formally placed under the command of the UNSG, whereas, traditionally, authorizations to the use of armed force are controlled by the contributing States. ${ }^{157}$ Second, considering super-robust mandates as authorizations to the use of armed force would conflict with the steady view of the UNSC and of its member States, according to which these missions are adopted in the framework of peacekeeping whereas authorizations of the use of armed force are coercive in nature and were created to replace operations under Article 42.

In this author's view, the main legal partitions of UNSC's operations are between Article 42 operations, in fact replaced by authorizations of the use of armed force, and peacekeeping missions. In the first instance, the UNSC decides to employ armed force but troops are controlled by the sending States, which conduct military operations without the consent of the State on whose territory the troops are deployed and operate (which is often the target of the action). In the second case, troops are deployed by the UNSC under the command of the UNSG, with the consent, at least, of the territorial State. It would be incorrect to consider in the same way operations undertaken against one State and operations undertaken with the consent of that State, ${ }^{158}$ despite the fact that the expression "authorization to take all necessary means" may be present in both scenarios. ${ }^{159}$

of control exercised by the UNSC does not mean that the authorized operations, in principle, would have been outside the remits of Art. 42 of the UN Charter, but rather, the UNSC should find a way to assert control over such operations in order to strengthen their legality and legitimacy (cf. T. Treves, Diritto internazionale: problemi fondamentali (Giuffrè, Milano, 2005), at 461-462, with A. Cassese, International Law (2nd ed., OUP, Oxford, 2005), at 349). In practice, the UNSC has exercised its responsibility under Art. 42 of the UN Charter through some authorizations of the use of armed force (see F.L. Kirgis, 'The Security Council's First Fifty Years', 89 AJIL (1995) 506, at 521 [doi:10.2307/2204171]; Sarooshi, supra n. 151, at 148, both referring to the consonance between the authorizations and the purpose of Art. 42). In particular, episodes such as the intervention in Kuwait in 1990 and in Libya in 2011 appear to fall within the remits of the actions that the UNSC would have undertaken under Art. 42, even though the UNSC failed to provide any control over the operations launched by the concerned States. Indeed, the UNSG, after having surveyed the practice of authorizations, invited the UNSC to revitalize the system created under Arts. $42 \mathrm{ff}$. to reach the same objectives pursued by the authorizations (An Agenda for Peace, supra n. 13, at paras. 42-43).

155 Note the articulated view of Cannizzaro, supra $\mathrm{n}$. 149, at 91-92, who differentiates between legality under UN law and under general international law.

156 Certain Expenses of the United Nations (Article 17, paragraph 2, of the Charter), Advisory Opinion of 20 July 1962, ICJ Reports (1962) 151 at 167.

157 See supra n. 154, on this issue in relation to the differences between authorizations and Art. 42 operations.

158 Vacas Fernández, supra n. 40, at 213-215; Picone, supra n. 8, at 73; Corten, supra n. 153, at 314.

159 Indeed, since the expression "authorization to take all the necessary measures/means" is employed by scholars to describe very different realities, the most correct approach should be analysing the legal basis of UNSC's authorizations of the use of armed force on a case-by-case basis (Picone, supra n. 8, at 9-10; Arcari, supra n. 151, at 
Accordingly, this author considers the consent or lack of consent of the territorial State to be the determining factor. Although the creation of the Intervention Brigade within MONUSCO, and the super-robust mandates of MINUSCA, MINUSMA, and UNMISS, have blurred significantly the difference between purely enforcement actions under Article 42 (rectius, the available mechanism of authorization to replace it) and peacekeeping far more than the robust mandates in the ${ }^{6} 90 \mathrm{~s},{ }^{160}$ it is not possible to equate these mandates with authorizations of the use of armed force. The fact that super-robust mandates are ultimately based on the consent of the territorial government and the operations are placed under the command of the UNSG bar such an equation.

Taking into account the most recent practice, this author believes that super-robust mandates should be considered as UNSC's interventions in NIACs, with the consent of the local government. ${ }^{161}$ Indeed, among many other responsibilities, MONUSCO, MINUSMA, MINUSCA, and UNMISS are acting alongside the government against some armed groups in ways that, if conducted by States outside the UN framework, would be considered as cases of intervention in a NIAC upon invitation. ${ }^{162}$

The idea that the UNSC takes part in NIACs on the side of the government thanks to that government's consent could appear in conflict with the fact that super-robust mandates are based on the consent and the invocation of Chapter VII. If the consent of the State is the primary legal basis of peacekeeping operations, even in super-robust mandates, one could wonder why the UNSC has felt the need to invoke also Chapter VII. Indeed, the ICJ considered the fact that UNEF I was based on the consent of the State as evidence of the non-forcible character of the mission. ${ }^{163}$ One may argue that Chapter VII is mentioned to circumvent the limits posed by Article 2(7) of the UN Charter, according to which the UN can intervene in matters within the domestic jurisdiction of a State only in the application of Chapter VII enforcement measures. However, this rule would not apply to forcible actions deployed with the consent of the government, which is free, under international law, to invite foreign troops to fight over its own territory. ${ }^{164}$ Indeed, in traditional peacekeeping, the consent is legally necessary exactly to overcome the barrier created by Article 2(7) of the UN Charter without the need to invoke

para. 2).

160 See Labuda, supra n. 149, at para. 19

161 See Y. Dinstein, Non-International Armed Conflicts in International Law (CUP, Cambridge, 2014), at 93-94. See, also, E. Lieblich, International Law and Civil Wars: Intervention and Consent (Routledge, Abingdon, 2013 ), at 2. 162 See M. Bennouna, Le consentement à l'ingérence militaire dans les conflits internes (LGDJ, Paris, 1976); V. Grado, Guerre civili e terzi Stati (Cedam, Padova, 1998); Lieblich, supra n. 161; P. Pustorino, Movimenti insurrezionali e diritto internazionale (Cacucci, Bari, 2018), at 227-262.

163 Certain Expenses opinion, supra n. 156, at 170-171.

164 Military and Paramilitary Activities in and Against Nicaragua (Nicaragua v. United States of America), ICJ Reports (1986) 14, at para. 246. See, also, Lieblich, supra n. 161, at 32. 
Chapter VII. ${ }^{165}$ Considering a reference to Chapter VII as legally needed ${ }^{166}$ for robust and superrobust mandates under the rules governing the action of the UN is also problematic since the UNSC has dispatched some robust missions without invoking it. ${ }^{167}$ Accordingly, one author has considered the invocation of Chapter VII just as "a safety belt" in relation to operations already based upon consent. 168

Another explanation for the invocation of both consent and Chapter VII reinforces the view that these mandates are forms of UNSC's interventions in NIACs. It may be the case that Chapter VII has been invoked because the missions have to be deployed in situations of NIACs where the government had partially lost control over some portions of its territory. According to an interpretation of the principles of non-intervention and self-determination of peoples particularly supported during the Cold War, a government loses its power to invite foreign troops over its territory if the NIAC has reached the level of a full-fledge civil war. ${ }^{169}$ Following the idea that the consent to the presence of peacekeeper is akin to the consent of the presence of foreign troops without UN mandate, it is possible to conclude that the UNSC prefers to invoke Chapter VII along with the consent of the State to justify the deployment of peacekeepers in situations where the effectiveness of the local government is doubtful.

Admittedly, this conclusion is devoid of consequences as per the legality of these missions, which is guaranteed by two solid legal grounds. Nevertheless, severing the link between superrobust mandates and peacekeeping would be useful to guarantee the integrity of the very idea of peacekeeping. ${ }^{170}$ Simply put, these super-robust missions are acting as those States that are intervening upon request of the government, often fighting armed groups together with the government and other States. Accordingly, they have a double character: they are consensual missions in relation to the host State and coercive missions in relation to some of the armed groups involved in the NIAC. This is not a novel scenario in the history of international maintenance of peace and security since, in the past, the UNSC has authorized coalitions of States or some international organizations to undertake similar operations, outsourcing the exercise of these coercive powers.171 However, it would be better if the UNSC renounced the label of peacekeeping in order to preserve the integrity of the very concept of peacekeeping

165 See, generally, F. Vacas Fernández, Las operaciones de mantenimiento de la paz de Naciones Unidas y el principio de no intervención. Un estudio sobre el consentimiento del Estado anfitrión (Tirant lo Blanch, Valencia, 2003); C.M. Díaz Barrado, F. Vacas Fernández, 'Fundamentos jurídicos y condiciones para el ejercicio de las operaciones de mantenimiento de la paz de Naciones Unidas', 21 AEDI (2005) 273, at 283-288.

166 Clearly, it is possible to consider the reference to Chapter VII as a measure to advance the legitimacy of an operation rather than as a source of its legality (see, e.g., I. Ingravallo, 'L'azione internazionale per la ricostruzione dell'Afghanistan', 59 Comunità Internazionale (2004) 525, at 543).

167 SC Res. 1701 (2006), 11 August 2006.

168 A. Paulus, 'Article 29', in Simma et al. (eds), supra n. 153, 539, at 554.

169 See L. Doswald-Beck, 'The Legal Validity of Military Intervention by Invitation of the Government', 56 BYBIL (1985) 189-252 [doi:10.1093/bybil/56.1.189]; Henderson, supra n. 15, at 360-368.

170 See HIPPO Report, supra n. 13, at para. 116.

171 For an overview on these operations, see Gargiulo, supra n. 150, at 945-947. 
(F) SUPER ROBUST MANDATES, PROTECTION OF CIVILIANS, AND THE ATTAINMENT OF A JUST TRANSITION FROM CONFLICT TO PEACE

\section{(1) General Criticisms}

Peacekeeping - through robust mandates, super-robust mandates, and the concept of stabilization - is one of the main tools employed by the UN to guide and govern the transition from a NIAC into peace. However, it is questionable whether an increase in the robustness of the mandates deployed in situations of NIACs contributes to achieving a lasting peace. ${ }^{172}$

The increased involvement of the UN and other international organizations in the transition from NIAC to peace has opened a significant debate on the legal principles that should guide such transition. A number of international rules, originating in international humanitarian law, international human rights law, UN law, and other branches of international law, concur with domestic law in the regulation of post-conflict situations so that the relevant legal framework is usually case-specific. Although some authors have suggested that a number of common trends are crystallizing into a corpus of rules often labelled as jus post bellum, ${ }^{173}$ this article prefers to refer to these principles as a set of objectives usually pursued by the UN in relation to post-conflict situations. ${ }^{174}$ A just transition from a situation of NIAC into peace requires the fairness and inclusiveness of the peace settlements, involving a just hearing of the interests of all parties to the conflict, the need to spare the civilian population in relation to the negative effects of UN involvement in the transition, and accountability for mass atrocities. ${ }^{175}$

The offensive nature of these super-robust mandates and the involvement of UN forces as parties in NIACs against armed groups make the attainment of the aforementioned principles problematic. MONUSCO, MINUSMA, MINUSCA, and UNMISS explicitly target some armed groups which are not meant to be included in post-conflict reconciliation. Rather, the UNSC decides which armed groups are to be considered potential partners in the peace process, and which ones are labelled as spoilers and quickly dismissed (sometimes after having been qualified as terrorist, as in the case of MINUSMA). Although this practice may be reasonable in certain circumstances in which some armed groups resort to heinous indiscriminate attacks against civilians in order to disrupt any attempt to achieve the peace, these missions are very likely to be

172 These considerations develop some of the arguments I have advanced in M. Longobardo, 'Robust Peacekeeping Mandates: An Assessment in Light of Jus Post Bellum, in C. Stahn and J. Iverson (eds), Just Peace After Conflict: Jus Post Bellum and the Justice of Peace (OUP, Oxford University Press, 2020) 165, at 181 -182.

173 See C. Stahn and J. Kleffner (eds), Jus Post Bellum Towards a Law of Transition from Conflict to Peace (TMC Asser, The Hague, 2008); L. May and A.T. Forcehimes (eds), Morality, Jus Post Bellum, and International Law (CUP, Cambridge, 2012); C. Stahn, J. Easterday and J. Iverson (eds), Jus Post Bellum: Mapping the Normative Foundations (OUP, Oxford, 2014); Stahn and Iverson (eds), supra n. 172.

174 E. De Brabandere, 'International Territorial Administrations and Post-Conflict Reforms: Reflections on the Need of a Jus Post Bellum as a Legal Framework', 44 RBDI (2011) 69-90.

175 C. Stahn, "Jus ad bellum, jus in bello . . jus post bellum? - Rethinking the Conception of the Law of Armed Force", EJIL (2016) 921, at 938-240 [doi:10.1093/ejil/chl037]; D. Fleck, "Jus Post Bellum as a Partly Independent Legal Framework", in Stahn, Easterday and Iverson (eds), supra n. 173, 43, at 55. 
perceived, at the best, as guests of the government that has consented to their deployment. In the worst scenario, armed groups may perceive peacekeepers as enemy, especially when troops from MONUSCO, MINUSMA, MINUSCA, and UNMISS support directly or indirectly the military operations of the government against those same armed groups. For instance, the Intervention Brigade appears to have been employed to pressure armed groups to discuss the terms of their surrenders, ${ }^{176}$ so that one may question the authenticity of these armed groups' consent to participate in the peace process.

The concerns regarding the cooperation of super-robust mandates with the local governments are particularly serious in relations to situations where peacekeepers side with forces that do not aim at reaching an inclusive peace or do not respect human rights. For instance, the SecretaryGeneral reported that the Congolese government was preventing the political participation of several groups ${ }^{177}$ and the $\mathrm{UN}$ faced certain embarrassment in supporting military operations led by Congolese armed forces under allegations of human rights abuses. ${ }^{178}$ Similarly, some human rights abuses related to military operations have been reported also in relation to the conduct of some governmental partners of MINUSCA. ${ }^{179}$ In order to avoid complicity in these violations, peacekeeping missions are following the Human Rights Due Diligence Policy on UN Support to Non-UN Security Forces, according to which UN support cannot be provided where there are grounds to believe that the receiving entities could commit grave violations of international law and where the relevant authorities fail to investigate them. ${ }^{180}$ Consequently, in 2015, MONUSCO refused to join a DRC operation due to allegations of human rights violations against recently appointed generals, ${ }^{181}$ even though the government launched that operation and did not remove those officials. ${ }^{182}$

In conclusion, super-robust mandates are not themselves in conflict with the attainment of a just transition from NIAC to peace in every circumstance. However, there is room to argue that proactive and offensive military operations by peacekeepers may contradict or endanger the goals of the UN.

\section{(2) The Effectiveness of Super-Robust Mandates}

This Section explores the effectiveness of super-robust mandates. A closer look into the situations affected by these mandates demonstrates that taking an offensive and proactive side with the local governments, in a way potentially incompatible with the principles of peacekeeping, does

176 S/2014/157, 5 March 2014, para. 18.

177 See, e.g., S/2015/172, 10 March 2015, paras. 4 and 57.

178 S/2016/579, 28 June 2016, para. 41. See also S/2016/833, 3 October 2016, para. 73.

$179 \mathrm{~S} / 2018 / 922,15$ October 2018, para. 21.

180 A/67/775-S/2013/110, 5 March 2013, para. 1. On the policy, see H.P. Aust, 'The UN Human Rights Due Diligence Policy: An Effective Mechanism against Complicity of Peacekeeping Forces?', 20 JCSL (2015) 61-73 [doi:10.1093/jesl/kru011].

$181 \mathrm{~S} / 2015 / 172,10$ March 2015, para. 37.

182 Ibid.; S/2016/233, 9 March 2016, para. 25. 
not enhance the achievement of the missions' goals.

Preliminarily, it is necessary to make a distinction between short-term and long-term goals of these missions. For instance, the action of all military components within MONUSCO, including the IB, achieved some important immediate goals, as the defeating of the armed group Mouvement du 23 mars. ${ }^{183}$ Similarly, UNMISS successfully secured the area of Juba from attacks launched by armed groups against the members of the mission and civilians alike. ${ }^{184}$

However, as for the long-term, MONUSCO proved unable to neutralize all the armed groups destabilizing the DRC. Rather, these groups are still active, and after several years of deployment of the IB, the situation of human rights and individual security in east DRC is still volatile. ${ }^{185}$ Moreover, in 2016 the Secretary-General reported that MONUSCO failed to implement an effective exit strategy, and its military components were still necessary to support the governmental authority against armed groups in certain areas. ${ }^{186}$ MONUSCO strengthened DRC governmental authority with its action, but failed to support military reforms that would have allowed the UN to give back to the Congolese government its responsibilities regarding the protection of civilians. From the aforementioned complaints of the Secretary-General about the lack of serious efforts by DRC regarding MONUSCO exit strategy (Intervention Brigade included), one might wonder whether such a super-robust support produced a tardiness in the DRC development of its own structures. Indeed, in 2016, the Secretary-General emphasized that MONUSCO's mandate (military components included) should have been renewed since it was vital for the protection of civilians and the fight against armed groups ${ }^{187}$ — demonstrating that after several years of MONUSCO's super-robust engagement, DRC is far from being pacified. The situation, however, improved by $2019 .{ }^{188}$

The counter-terrorism mandate of MINUSMA has not been effective in stabilizing the region, but rather, the Secretary-General has reported that the security situation in Northern and Central Mali is still problematic. ${ }^{189}$ Similarly, MINUSCA proved unable to stabilize the Central African Republic, as noted by the Secretary-General in 2018.190 Only after the conclusion of the 2019 Political Agreement for Peace and Reconciliation, was the Secretary-General able to report some improvement in the security situation. ${ }^{191}$

Furthermore, the lack of impartiality of missions such as MONUSCO, MINUSMA, MINUSCA,

183 S/2013/757, 17 December 2013, paras. 2 and 97; D. Tull, 'UN Peacekeeping Missions During the Past Two Decades. How Effective Have They Been?', in J. Krause and N. Ronzitti (eds), The EU, the UN and Collective Security (Routledge, Abingdon, 2012) 117, at 182.

$184 \mathrm{~S} / 2017 / 328,17$ April 2017, 2-3.

185 See, e.g., S/2016/579, 28 June 2016, para. 21; S/2017/206, 10 March 2017, paras. 28-34; S/2019/905, 26 November 2019, paras. 13-21.

186 See, e.g., S/2016/233, 9 March 2016, para. 74.

187 Ibid.

$188 \mathrm{~S} / 2019 / 905,26$ November 2019, para. 55.

$189 \mathrm{~S} / 2019 / 983,30$ December 2019, para. 43

$190 \mathrm{~S} / 2018 / 922,15$ October 2018, para. 4.

191 S/2020/124, 14 February 2020, paras. 3 and 89. 
and UNMISS might have worsened the safety and security conditions of UN troops. In relation to MONUSCO, immediately after the creation of the IB, the Secretary-General feared an escalation of threats. ${ }^{192}$ However, subsequently he reported that there was no general increase in danger, ${ }^{193}$ but, rather, armed attacks only became more frequent in certain areas. ${ }^{194}$ Nonetheless, in December 2017, MONUSCO suffered the most serious attack ever in the history of UN peacekeeping. ${ }^{195}$

Likewise, in relation to MINUSCA, the Secretary-General confirmed that the security of the mission is still in danger, ${ }^{196}$ expressing concerns over risks linked to the mission's support to the government. ${ }^{197}$ In Mali, the very robust approach of MINUSMA to terrorist treats has resulted in a perverse competition between local security forces and peacekeepers, who are perceived as competitors in relation to the maintenance of public order. ${ }^{198}$ Indeed, in recent years, MINUSMA has been progressively targeted by armed groups on a number of occasions. ${ }^{199}$ From a wider perspective, the case of UNMISS shows that super-robust mandates do not guarantee the safety and security of the UN troops, since the UNSC had to modify the already robust mandate of UNMISS in 2016 to create a specific unit with the task to protect the entire mission.

A 2017 UN report on Improving Security of UN Peacekeepers, drafted by a former MONUSCO's commander, acknowledged that most casualties in peacekeeping occurred in the framework of MINUSMA, MINUSCA, and MONUSCO. 200 This is an obvious consequence of the involvement of these peacekeepers as parties to the relevant armed conflicts, where they could be lawfully targeted by armed groups as combatants pursuant to international humanitarian law. ${ }^{201}$ Indeed, the 1998 Rome Statute of the International Criminal Court criminalizes direct attacks against peacekeepers only "as long as they are entitled to the protection given to civilians or civilian objects under the international law of armed conflict". ${ }^{202}$ Although whether the authorization of the use of force embodied in super-robust mandates has changed the civilian nature of peacekeepers is an issue that should be analysed case-by-case, ${ }^{203}$ it is significant that

192 S/2013/581 (2013), 30 September 2013, paras. 66-68; S/2017/206, 10 March 2017, para. 64.

193 See, e.g., S/2014/698, 25 September 2014, para. 84; S/2016/233, 9 March 2016, para. 64.

194 S/2014/956 (2014), para. 34; S/2015/172 (2015), para. 45. See, also, S/2017/206, 10 March 2017, para. 51.

195 See UN Press Release, 'At Least 71 United Nations Associated Personnel Killed in Malicious Attacks against Peacekeeping Operations during 2017', 21 January 2018.

$196 \mathrm{~S} / 2018 / 922,15$ October 2018, para. 83.

$197 \mathrm{~S} / 2020 / 124,14$ February 2020, para. 91.

$198 \mathrm{~S} / 2019 / 983,30$ December 2019, para. 51.

199 See, e.g., UN Press Release, 'At Least 51 United Nations Personnel Killed in Deliberate Attacks against Peacekeeping Operations in 2015, 21 January 2016; UN Press Release, supra n. 195; S/2019/983, 30 December 2019 , para. 94.

200 C.A. Santos Cruz, Improving Security of UN Peacekeepers: We Need to Change the Way We Are Doing Business (UN, New York, 2017), at 5.

201 M.A. Khalil, 'Robust Peacekeeping-Not Aggressive Peacekeeping', 112 Proceedings of the ASIL Annual Meeting (2018) 114, at 116 [doi:10.1017/amp.2019.14].

202 Art. 8(2)(b)(iii) and Art 8(2)(e)(iii), Rome Statute of the International Criminal Court, 2187 UNTS 90.

203 See ICC, Prosecutor v. Bahar Idriss Abu Garda (Case no. ICC-02/05-02/09), Decision on the Confirmation of Charges, No. ICC-02/05-02/09-PT, 8 February 2010, para. 83. 
international criminal tribunals have acknowledged that these mandates have diluted the basic features of peacekeeping, impairing the legal protection of the peacekeepers. ${ }^{204}$ Surprisingly, the aforementioned 2017 report recommends an even more robust military response to armed threats, including the launching of offensive strikes to get rid of the "Chapter VI Syndrome" and selfdefence concerns. ${ }^{205}$ This stance, if followed by the UNSC, would dangerously shift the main focus of peacekeeping from protection of civilians to protection of the force itself. ${ }^{206}$

Although super-robust mandates may have some immediate positive effects on communities that are striving to emerge from an internal armed conflict, in the long term, they may not be effective at addressing the roots of the conflict, but rather, peacekeepers may become just additional actors involved therein. This is the consequence of the perception of these mandates by those same armed groups that are to be neutralized or treated as terrorists by the peacekeepers, which engages the UN troops exactly with the same hostile stance as they engage the enemy governmental force.

\section{(G) CONCLUSIONS}

The need for robust mandates to protect civilians does not imply a need for aggressive mandates. ${ }^{207}$ The increasingly popularity of super-robust mandates after the creation of the Intervention Brigade in 2013 poses significant challenges to the legal understanding of peacekeeping, due to the impossibility to consider these missions as impartial and as a result of the unprecedented degree of offensive armed force that they can employ. However, these mandates do not fall within the traditional understanding of Article 42 operations or of authorizations of the use of armed force, since they are still based on the consent of the territorial government and are placed under the command of the UNSG. Their effectiveness is questionable in light of the surge of attacks faced by MONUSCO, MINUSMA, MINUSCA, and other missions after the UNSC has attributed them offensive mandates. Rather, often these mandates further complicated the already blurred divide between peacetime and wartime in international law, endangering the safety of civilians and non-offensive military components of peacekeeping missions around the world.

This article does not advocate for more authorizations to the use of armed force, à la Libya in 2011, which dramatically increased the chaos in the country and worsened the life conditions of the civilian population. ${ }^{208}$ Additionally, non-legal considerations - e.g. those related to the reluctance of individual States or international organizations to lead authorized coalitions - may influence the decision to dispatch a super-robust mandate allegedly in the framework of

204 See Sesay, Kallon and Gbao case, supra n. 51, at para. 223.

205 Santos Cruz, supra n. 200, at 11.

206 See Lyons, supra n. 37, at 110.

207 Khalil, supra n. 201, at 116.

208 See, e.g., A.J. Kuperman, 'Obama's Libya Debacle: How a Well-Meaning Intervention Ended in Failure', 94 Foreign Affairs (2015) 66-77. 
peacekeeping. However, it is not even possible to accept the characterization as peacekeeping of every mission, irrespective of its compliance with the principles of peacekeeping, on the basis of an act of faith in the words of the UNSC. 